Bathó Gábor

\title{
HATÁSKÖRI ÖSSZEÜTKÖZÉSEK ÉS KIHÁGÁSOK A MINISZTERTANÁCS ELÖTT
}

\section{Conflicts of Competence and Petty Offences before the Council of Ministers}

Bathó Gábor tanársegéd, Nemzeti Közszolgálati Egyetem Államtudományi és Nemzetközi Tanulmányok Kar Állam- és Jogtörténeti Tanszék, batho.gabor@uni-nke.hu

A minisztertanácsi jegyzőkönyveket vizsgálva azt állapithatjuk meg, hogy alapvetöen háromféle módon jelentek ott meg a kihágások. Egyrészt a kihágásokkal kapcsolatos feladatok intézése mint minisztériumi ügykör, másrészt a kihágásokkal kapcsolatos jogszabályok előkészitése, harmadrészt pedig mint kihágásokkal kapcsolatos hatásköri összeütközések. A bírósági reform elkezdéséhez kapcsolódó kompromisszum eredménye lett az 1869. évi IV. törvénycikk 25. \$-a, amely a közigazgatási hatóságok és a biróságok közötti hatásköri összeütközések rendezésének kérdését szabályozta, ideiglenesen. Szerencsétlen volt a szabályozás, mivel a kormánynak olyan kérdésekkel kellett foglalkoznia, amelyekhez sem a szükséges tudása, sem a szükséges kompetenciái, sem pedig a szükséges mennyiségü ideje nem állt rendelkezésre. Ráadásul - különösen a kihágások esetén - olyan ügyeket kellett a kormány elé vinni, amelyek jelentősége nagyon csekély volt. A kortársak szerint a kormány megfelelö önmérséklettel és óvatossággal járt el a hatásköri összeütközések feloldásánál. Azonban erre semmilyen jogszabály nem kényszerítette, semmilyen jogi jellegü garanciális elem sem volt a kormány eljárásában. A helyzet valódi megoldását a hatásköri bíróságokról szóló törvény hozta el 1907-ben.

KulCsSzAvaK:

hatásköri bíróság, hatásköri összeütközés, kihágás, kormány, minisztériumi ügykör

Examining the minutes of the Council of Ministers, we can state that there were basically three ways in which the petty offences appeared there: firstly, the management of tasks related to petty offences as ministerial competence, secondly, the preparation of legislation related to petty offences, and thirdly as conflicts of competence related to petty offences. One of the results of the compromise associated with the commencement of judicial reform was the adoption of Article 25 of Act IV of 1869, which temporarily regulated the issue of resolving conflicts of competence between administrative authorities and courts. The regulation was unfortunate because 
the government had to deal with issues for which it did not have the necessary knowledge, the necessary competencies, or the required amount of time. In addition, especially in case of petty offences, cases had to be brought before the government that were of very little importance. According to contemporaries, the government acted with due restraint and caution in resolving conflicts of competence. However, this restraint was not forced by any legislation, nor was there any legal guarantee element in the government proceedings. The real solution to the situation was brought in 1907 by the Competence Court Act.

KEYWORDS:

court of competence, conflict of competence, petty offence, government, ministerial competence 


\section{BEVEZETÉS}

Ebben az írásban a minisztertanács és a kihágások kapcsolatát vizsgálom meg a minisztertanács napirendjeiből kiindulva. A minisztertanácsi jegyzőkönyveket vizsgálva azt állapíthatjuk meg, hogy alapvetően háromféle módon jelentek ott meg a kihágások. Egyrészt a kihágásokkal kapcsolatos feladatok intézése mint minisztériumi ügykör, másrészt a kihágásokkal kapcsolatos jogszabályok előkészítése, harmadrészt pedig mint kihágásokkal kapcsolatos hatásköri összeütközések.

\section{MINISZTÉRIUMI ÜGYKÖRÖK RENDEZÉSE}

A független magyar felelős ministerium alakításáról szóló 1848. évi III. törvénycikk 16. §-a úgy rendelkezik, hogy a „kebelébeni ügykezelés módját a ministerium maga határozandja meg". E rendelkezés gyakorlatban kialakított tartalmának megfelelően a kormány az egyes ügyköröket az egyik minisztérium hatásköréből egy másik minisztérium hatáskörébe helyezhet át. Egy ilyen ügyköráthelyezést rendszerint egy sor esemény követ, amely eseménysorban valahol törvényi szintű jogalkotás is megjelenik. Az ügyköráthelyezésről szóló kormánydöntést általában egy miniszteri rendelet követi, amelyet gyakran közösen, az ügykörmódosításban érintett miniszterek együttesen bocsátják ki. Ha az ügykörmódosítás költségvetési forrásokat is érint, akkor erről az adott év tekintetében születik miniszteri vagy kormányszintű döntés, ritkán törvény. Ha az ügykörmódosítás állandósulni látszik, akkor az beépül a következő évi költségvetésbe, így végső soron törvényi szintű szabályozásban, a költségvetési törvényben jelenik meg.

Az alábbiakban a kihágásokkal kapcsolatban egy szabályt erősítő kivételt mutatok be. A minisztertanács 1870. július 21-ei ülésén döntött arról, hogy a mezei és erdészeti kihágási ügyeket a Földművelés, Ipar- és Kereskedelemügyi Minisztérium hatásköréből a Belügyminisztérium hatáskörébe helyezi át. ${ }^{2}$ Ezt azonban sem 1870-ben, sem 1871-ben nem követte rendeletalkotás. Ugyancsak nem jelent meg a kérdés a következő költségvetési törvényekben sem. Ez nem meglepő arra tekintettel, hogy erre az időszakra részköltségvetések láncolata alakult ki, amely az 1869. évi költségvetésen ${ }^{3}$ alapult. ${ }^{4} \mathrm{~A}$ mezei és erdészeti (erdei)

1848. évi III. tc. 16. §.

MNL W12 Minisztertanácsi jegyzőkönyvek (K27) 1867-1944. 1870. július 21. (53. ülés).

1868. évi L. törvénycikk az 1869-ik évi államköltségvetésről.

A költségvetési törvények láncolata a következőkből áll az 1870. és 1871. éveket tekintve: az 1869-es költségvetést megállapító 1868. évi L. törvénycikkre építve fogadták el az 1870-ik év január 1-től ugyanazon év márczius 31-ig viselendő közterhekről és fedezendő kiadásokról szóló 1869. évi XXVI. törvénycikket, ezt követően az 1869. évi XXVI. törvénycikk hatályának kiterjesztéséről szóló 1870 . évi IV. törvénycikket, amely 1870. április 30-ig terjesztette ki az ideiglenes állapotot azzal, hogy ha időközben szentesítik az éves költségvetésről szóló törvényt, akkor ez hatályát veszti. Ezt minisztériumonkénti póthitelek követték (a honvédelmi ministernek 1870. évre megszavazandó öt millió forintnyi póthitelről szóló 1870. évi XLIV. törvénycikk, a közbiztonság helyreállitása végett tett rendkivüli intézkedések befejezéséhez megkivántató póthitelről szóló 1870. évi XLV. törvénycikk, a vallás- és közoktatási minister 1870. évi kiadásainak fedezésére szolgáló póthitelről szóló 1870. 
kihágásokkal kapcsolatban az ezt követő években több rendelet is született, ${ }^{5}$ amelyek bár érintették a mezei és erdei kihágásokat, de nem a belügyminisztertől vagy a földművelés-, ipar- és kereskedelemügyi minisztertől származtak. A kérdést végső soron az erdőtörvény ${ }^{6}$ rendezte, amelynek végrehajtására már gyakran a belügyminiszter, de szintén igen gyakran a földmüvelés-, ipar- és kereskedelemügyi miniszter is bocsátott ki rendeleteket. ${ }^{7}$ Úgy tünik, mintha az ügykörátrendezésről szóló kormánydöntésnek éveken keresztül nem lett volna hatása.

\section{TÖRVÉNY-ELÖKÉSZÍTÉS}

A minisztertanácsnak feladata van a törvények előkészítési szakaszában is, dönteniük kellett a törvénytervezetek uralkodó, illetve országgyülés elé terjesztéséről is. Mivel nem ennek értékelése a jelen írás tárgya, ezért csak példaképpen két alkalmat említek. A minisztertanács 1878. december 27-én 6. napirendi pontként megadta a felhatalmazást az igazságügyminiszternek, hogy a rendőri kihágásokról szóló büntető törvényjavaslatot a bizottsági tárgyalás után az országgyűlésnek előterjessze. ${ }^{8}$ A minisztertanács 1897. február 10-ei ülésének napirendjén pedig szerepelt a büntető törvénykönyv (1878: V. tc.) és a kihágási büntető törvénykönyv (1879: XL. tc.) módosításáról szóló törvényjavaslat bemutatása. ${ }^{9} \mathrm{Az}$ igazságügy-miniszter előterjesztését itt is elfogadta a minisztertanács, megkapta a felhatalmazást, hogy uralkodói jóváhagyás után az országgyülés elé terjessze

évi XLVI. törvénycikk). Az 1871-es év is hasonlóan, részköltségvetésekkel kezdődött: az 1871. évi január 1-től ugyanazon évi február végeig viselendő közterhekről és fedezendő kiadásokról szóló 1870. évi XLVIII. törvénycikkel, valamint az 1871. évi márczius hóban viselendő közterhekről és fedezendő kiadásokról szóló 1871. évi II. törvénycikkel. Végül az 1871. évi államköltségvetésről szóló 1871. évi X. törvénycikk rendezte a helyzetet.

Lásd pl.: A m. k. igazságügyministernek 1871. decz. 12-én 10.222. sz. a. kelt utasítása a szervezendő kir. bíróságok életbeléptével feloszlatandó elsőfolyamodásu biróságok iratainak, az ezek által kezelt letéteknek, telekkönyveknek átadása, valamint a törvényhatósági börtönök s fogházakban letartóztatott foglyok átszállítása tárgyában. (Magyarországi rendeletek tára 1871. Pest, Ráth Mór, 1871. 382-392.); A m. kir. vallás- és közokt. ministertől 1871. október 10-én 22.392. szám alatt kiadott szolgálati utasítás a közalapítványi kir. erdészek számára. (Magyarországi rendeletek tára 1871. Pest, Ráth Mór, 1871. 461-474.); A vallás és közoktatási m. k. ministernek f. évi 20,377. sz. a. valamennyi megye tanfelügyelőjéhez és az egyházi hatóságokhoz intézett körlevele: a községi faiskolák berendezése tárgyában. (Magyarországi rendeletek tára 1875. Budapest, Vodianer, 1875. 488-497.)

1879. évi XXXI. törvénycikk Erdőtörvény.

Lásd pl.: A m. kir. belügyministernek 37,635. számú körrendelete, az uj erdőtörvény életbelépte elött elkövetett erdei kihágások elbirálása tárgyában. (Magyarországi rendeletek tára 1880. Budapest, M. Kir. Belügyministerium, 1880., 627-628.); A földmivelés-, ipar- és kereskedelemügyi m. kir. minister által 24,432. szám alatt kiadott utasitás, az erdei kihágási biróságok által használandó érték- és árszabályzatok kidolgozásánál követendő eljárás tárgyában. (Magyarországi rendeletek tára 1880. Budapest, M. Kir. Belügyministerium, 1880., 682-696.) A földmivelés-, ipar- és kereskedelemügyi m. kir. minister által 24,931. szám alatt kiadott utasitás, az erdei kihágások feljegyzésére szolgáló erdei rovatos naplók készitése és vezetése tárgyában. (Magyarországi rendeletek tára 1880. Budapest, M. Kir. Belügyministerium, 1880. 704-712.).

B MNL W12 Minisztertanácsi jegyzőkönyvek (K27) 1867-1944. 1878. december 27. (42. ülés).

9 MNL W12 Minisztertanácsi jegyzőkönyvek (K27) 1867-1944. 1897. február 10. (6. ülés). 
a módosító javaslatot. Tekintettel arra, hogy a minisztertanácsi jegyzőkönyvek csak ritkán, nagyobb viták esetén tartalmaznak erre való utalást, azt mondhatjuk, hogy e két esetben nem volt jelentősebb vita a kormánytagok között.

\section{HATÁSKÖRI ÖSSZEÜTKÖZÉSEK}

„Hja, Jani bátyám, idelent van a közigazgatás súlypontja. Azok odafent azt teszik, amit a törvény előír, mink meg azt, amit ezeknek a szegény ördögöknek az élete parancsol. Közigazgatunk; nem ahogy rendelik, hanem, ahogy lehet, Jani bátyám.” ${ }^{10}$ Kilián Zoltán szomorú novellájának közigazgatásra vonatkozó tanulsága jól illik majd ezen írás tanulságához is. A közigazgatási hatóságok és bíróságok közötti hatásköri összeütközések kormány általi rendezése azt a helyzetet okozta, hogy „a fent lett a lent”, azaz a kormánynak olyan ügyekben kellett döntést hoznia, amelyek jelentőségüknél fogva nem illeszkedtek a többi, kormány által eldönteni rendelt kérdés közé.

Ezen írás szűkebben vett célja a kihágásokkal kapcsolatos hatásköri összeütközések eldöntése gyakorlatának bemutatása. 1869 és 1908 között a kormány volt jogosult e döntéseket meghozni, a kormányt testületként illette ez a feladat. Így a minisztertanácsok napirendjét olvasva olyan jelentősnek nem mondható napirendi pontokkal találkozhatunk, mint „hatásköri összeütközés a M. Kir. Kúria és Szepes megye Másodfokú Erdei Kihágási Bírósága között Zsemba József és Zsemba János juhai által okozott kár ügyében"11 vagy „hatásköri összeütközés a gyöngyösi járás szolgabírói hivatala és a Gyöngyösi Kir. Járásbíróság között Szász Jánosné kuruzslónő közegészség elleni kihágási ügyében”. ${ }^{12}$

A kormány hatásköri összeütközések elrendezésére irányuló feladatának az alapja a bírói hatalom gyakorlásáról szóló 1869 . évi IV. törvénycikk, illetve annak 25 . $\$$-a, amely szerint a „biró s közigazgatási hatóságok közt felmerült illetőségi összegzések elintézésére, a törvényhozás további intézkedéséig a ministerium hatalmaztatik" ${ }^{13}$ A törvénycikk e rendelkezése mintha ellentétben állni látszana az 1. \$-ban írt alaptétellel, amely szerint az „igazságszolgáltatás a közigazgatástól elkülöníttetik. Sem a közigazgatási, sem a birói hatóságok egymás hatáskörébe nem avatkozhatnak." ${ }^{14}$ Az ellentét abból ered, hogy a bíróságok és a közigazgatási szervek (mint két különböző hatalmi ág részei) közötti vitákat a végrehajtás csúcsán álló szerv, a kormány dönti el. Tekintettel arra, hogy a végrehajtás teljesen más alapelvek szerint működik, mint az igazságszolgáltatás, ez a szabályozási konstrukció aggályokat ébreszt.

\footnotetext{
Kilián Zoltán: Erdei kihágás. Napkelet, 4. (1926), 9. 846-853. 851.

11 MNL W12 Minisztertanácsi jegyzőkönyvek (K27) 1867-1944. 1884. március 18. (8. ülés). Ekkor ez volt a 25. napirendi pont.

12 MNL W12 Minisztertanácsi jegyzőkönyvek (K27) 1867-1944. 1885. június 8. (12. ülés). Ekkor ez volt a 16. napirendi pont.

13 1869. évi IV. tc. 25. \$.

14 1869. évi IV. tc. 1. \$.
} 
A bírói hatalom gyakorlásáról szóló törvény javaslata ${ }^{15}$ a későbbi 25 . \$-t még 24 . \$-ként tartalmazta, nagyjából hasonló szövegezéssel: „A bíró s közigazgatósági hatóságok közt felmerült illetőségi összeütközések elintézése, a törvényhozás további intézkedéséig a ministeriumot illeti." ${ }^{\prime 16}$ A képviselőházi vita során sok szempontból fogalmaztak meg a képviselők aggályokat, így a bírói döntés szükségessége, a hozzá nem értés, az alkotmányos rendbe való nehézkes beilleszthetőség, az ideiglenesség, a túlzott centralizmus, a külföldi példák figyelembevétele, illetve az egyéni felelősség helyett a kollegialitás elve szempontjából.

A képviselőházi vita során Győrffy Gyula képviselő a törvényjavaslat 1. \$-ában írt alaptétellel kapcsolatban mondta el aggályait. Azt mondta, hogy senki sem vonhatja kétségbe azt az elvet, „miszerint a birói és közigazgatósági hatóságok közt előfordulható illetőségi összeütközések felett a bíráskodás, valamint általában véve, minden bíráskodás, a törvény alkalmazásának kérdése lévén, a birói jog köréhez tartozik" ${ }^{17}$ Álláspontja szerint, ha a hatásköri összeütközések kezelésének kérdése tekintetében a törvényjavaslat szerinti szöveget fogadná el a Képviselőház, azaz a kormány lenne jogosult a közigazgatási hatóságok és bíróságok közötti hatásköri összeütközések eldöntésére, akkor ezzel az 1 . $\$$ szerinti alapelv megdőlne. ${ }^{18}$ Győrffy képviselő aggályaival magam is egyetértek, legfinomabban fogalmazva sem szerencsés az a választás, amely szerint a közigazgatási szervek és a bírói szervek közötti hatásköri vitákat a kormány mint a közigazgatás csúcsszerve döntse el.

A későbbiek szempontjából fontos annak vizsgálata már e ponton, hogy az 1869. évi IV. törvénycikk 25. \$-ában írt hatásköri összeütközés esetén mit bírál el a kormány. Különösen szembetűnő ez a szűkebb témánk, a kihágások szemszögéből nézve. A leggyakrabban előforduló hatásköri összeütközés negatív hatásköri összeütközés volt, azaz előbb a közigazgatási vagy bírói szerv állapította meg hatáskörének hiányát, majd a másik szerv tette ugyanezt. Tehát amikor a kormány eldönti a negatív hatásköri összeütközést, azt dönti el, hogy a közigazgatásra vagy az igazságszolgáltatásra tartozik a kérdés eldöntése. Azaz másként fogalmazva, a kormány azt dönti el, hogy az igazságügy-miniszter kormány számára készített előterjesztésében írt cselekmény elbírálása bíróság vagy közigazgatási hatóság kötelezettsége-e. Kihágások, vétségek, bűntettek esetében az eljárásra hatáskörrel rendelkező szerv megállapításának alapja pedig az, hogy a cselekmény hogyan minősül. Alapvetően az 1878. évi V. törvénycikk ${ }^{19}$ és az 1879 . évi XL. törvénycik $k^{20}$ határozza meg a cselekmények minősítésének lehetőségeit. E törvénycikk hatálybalépésével kapcsolatos részletszabályokat, átmeneti rendelkezéseket (ahogyan a Csemegi-kódex 486. \$-a ${ }^{21}$

\footnotetext{
Képviselőházi Irományok, 1. (1869), 20. 58-60.

Képviselöházi Irományok, 1. (1869), 21. 60.

Képviselőházi napló 1869, II. kötet, 493.

Uo.

1878. évi V. törvénycikk a magyar büntetőtörvény a büntettekről és vétségekről.

1879. évi XL. törvénycikk a magyar büntetőtörvénykönyv a kihágásokról.

„486. $§$ A jelen törvény végrehajtásával az igazságügyi minister bizatik meg, hatálybaléptének idejéről és az átmeneti intézkedések iránt külön életbeléptetési törvény rendelkezik.”
} 
és a Kbtk. 144. \$-a ${ }^{22}$ rögzítette) az 1880. évi XXXVII. törvénycikk ${ }^{23}$ tartalmazta. E törvénycikk 39-41. \$-aiban hatásköri szabályokat is tartalmazott a kir. törvényszékek, a kir. járásbíróságok és a közigazgatási hatóságok tekintetében. A hatáskör megállapításának az alapjai pedig legnagyobbrészt az eljárások tárgyát képező kihágások és vétségek. Tehát, amikor a kormány dönt egy közigazgatási hatóság és bíróság között fennálló hatásköri összeütközés kérdésében, akkor az igazságügy-miniszter által előterjesztett tényállás alapján arról dönt, hogy véleménye szerint hogyan, miként minősül az alapul fekvő ügyben elkövetett cselekmény. Erre tekintettel értek egyet Győrffy Gyula aggályaival, hiszen még a pusztán cselekmény előzetes minősítése esetében is helyesebb volna egy bírói szerv döntését kérni.

Az 1869. évi IV. törvénycikk leendő 25. \$-ának vitájában a második jelentős vitatéma a szabályozás ideiglenessége volt. Tudvalevő, hogy ez a szabályozás egy nagyobb törvénycsomag része volt, azonban a többi, az igazságügyi reformra vonatkozó részelem elfogadására csak évekkel később került sor. Plachy Tamás képviselő felvetése egészen logikus volt: „Midőn törvényt alkotunk, törvényt a birói hatalomra vonatkozólag, akkor nem látom szükségét, hogy ideiglen hatalmazzunk fel bárkit, miután előttünk áll a lehetőség, hogy az elintézést azonnal codificáljuk, törvénybe iktassuk.” ${ }^{24}$ A 25. \$ szabályozása kifejezetten ideiglenes, a szabályt „a törvényhozás további intézkedéseig” állapítja meg. Várady Gábor azt rótta fel az igazságügyminiszternek, illetve a kormánynak, hogy „miért nem terjesztett elő egy az egész rendszert átölelő törvényjavaslatot, miután a még a többségből alakult központi bizottság is kijelentette szükségét annak, hogy egy legfőbb állambiróság mielőbb életbe léptettessék” ${ }^{25}$ Maga Deák Ferenc is - a képviselőházi vita vége felé - sürgette azt, hogy „határozza el a ház, hogy az igazságügyminiszter egy felállítandó legfelső állambiróság iránt mielőbb törvényjavaslatot terjeszszen a ház asztalára”. ${ }^{26}$ Valóban nem tünik logikusnak, hogy egy éppen szabályozás alatt lévő témáról szóló törvényjavaslatba olyan elem kerüljön, ami ideiglenes, és amelynek rendezésére nincs terv belátható időn belül. Az igazságügyi reform éveken belül tovább zajlik majd, azonban a kormány számára az 1869. évi IV. törvénycikkel biztosított hatáskör még 40 évig megmarad. Többször is felmerült a vita során az úgynevezett legfelső állambíróság felállításának szükségessége, de ezt a gondolatot nem bontották ki jobban, és tettek sem követték. A törvényjavaslatot véleményező - és bőséges módosító javaslatot megfogalmazó - bizottság is ezen az állásponton volt, azaz az állambíróság felállítását támogatta. Horváth Döme, a bizottság előadója a képviselőházi vita végén elmondta: „[A]zon óhajtását fejezi ki a központi bizottság, hogy határozatilag mondja ki a ház: miszerint az igazságügyminiszter egy felállítandó legfelsőbb állambiróság iránti törvényjavaslatát mielébb terjeszsze a ház elé." ${ }^{27} \mathrm{Ez}$ sem történt meg.

\footnotetext{
„144. $\$$ A jelen törvény hatályba lépte és az átmeneti intézkedések iránt külön életbeléptetési törvény rendelkezik."

23 1880. évi XXXVII. törvénycikk a magyar büntető törvénykönyvek életbeléptetéséről.

24 Képviselőházi napló 1869, II. kötet, 110.

25 Képviselőházi napló 1869 , II. kötet, 76.

26 Képviselőházi napló 1869, II. kötet, 442.

27 Képviselőházi napló 1869, II. kötet, 495.
} 
A harmadik jelentős - az igazságügyi reform során talán a legjelentősebb - vitatéma a centralizáció kérdése volt, amit egyesek a kormány túlhatalmával azonosítottak. Az egész vitának eleve ez, a municipalista-centralista vita volt a központja, így nyilvánvaló volt, hogy ez a hatásköri összeütközések kérdésében is meg fog jelenni. Különösen úgy, hogy a hatásköri összeütközések kérdésében a kormány olyan hatáskört kapott, amelynek kormányra telepítése - különösen az ellenzék szerint - nem volt szükséges. Plachy Tamás képviselő is erre utalt, amikor a vita során ezt mondta: „Nem kell nekünk [...] az igazságügyminiszter ur teljes centralisatiója, és nem kell [...] a miniszteri mindenhatóságnak növelése. Nem kell nekünk az igazságügyminiszter merev centralisatiója: mert azt hiszem, azzal kormányozni ugyan könnyebb és kényelmesebb, de az egyéni szabadság garantiáját a centralisatióban - legyen az törvénykezési vagy közigazgatási centralisatio - egyátalán nem található fel. A miniszteri mindenhatóságot is kiemeltem, mint olyat, mely nekem nem kell." ${ }^{28}$ Nemcsak egyszerüen a centralizációt utasították el, hanem annak minden elemét is, hogy a központi kormányzat további hatásköröket szerezzen. Így egyértelmü volt, hogy ebből a szempontból teljes elutasítást fog kapni a törvénytervezet hatásköri összeütközésekkel kapcsolatos rendelkezése a municipalistáktól.

A következő szempontból nézve a javaslatot szintén nagyon helyénvaló a megfogalmazott kritika. Eszerint a közigazgatási hatóságok és a bíróságok között felmerült hatásköri összeütközések eldöntése esetében nem közigazgatási döntésről van szó, hanem olyan döntésröl, amely az igazságszolgáltatásra tartozik, így bírói szervnek kell meghoznia. Tekintettel arra, hogy a kormány egy teljesen más elvek alapján müködő hatalmi ágnak, a végrehajtásnak a csúcsszerve, nem tudja és nem is láthatja el ezt a feladatot megfelelően. Várady Gábor megfogalmazása szerint: „A kik a bírói felelősség szükségét érzik, ugy mint mi, azok, kik azt biztosítani akarják, ugy mint mi, azok nem fognak örülni ezen administrationalis intézkedésnek." ${ }^{29}$ Várady képviselő a bírói felelősséggel meghozott döntésnek épp azokat az ismérveit kérte számon, amelyeket az 1869. évi IV. törvénycikk határozott meg világosan. Azzal, hogy a törvényjavaslat a közigazgatási hatóságok és bíróságok közötti hatásköri összeütközések rendezésének feladatát a kormányra bízta, a polgári igazságszolgáltatásnak és éppen annak a törvénynek az elveit sérti meg, amelyben ezt a kormányhatáskört rögzítik. Ezzel vissza is jutottunk a kritikák legelső szempontjáig, amely szerint a kormánynak ez a hatásköre a törvény 1 . $\$$-ával áll ellentétben.

Ghyczy Kálmán - mint az áprilisi törvények egyik megszövegezője ${ }^{30}$ és így a polgári átalakulás egyik vezéralakja - egyenesen szégyennek nevezi a törvényjavaslat szerinti konstrukciót, külön kiemeli, hogy még Oroszországban is bírói szervek döntenek az ilyen hatásköri összeütközésekben: „[A] minisztérium még azon kérdés elhatározását is, hogy: mi az, a mi a bíróságok, mi az, a mi a közigazgatási hatóságok köréhez tartozik? önmagának tartja fen; s e tekintetben megszégyenittetni engedi magát még az oroszországi

Képviselőházi napló 1869, II. kötet, 110.

Képviselőházi napló 1869, II. kötet, 76.

Nagy Miklós: Ghyczy Kálmán, mint nádori ítélőmester. Budapesti Szemle, 219. (1930), 635. 1-28. 
törvényhozás által is; mely a most uralkodó czár 1864 év november 20-án kiadott rendelete $^{31}$ szerint az ily illetékességi összeütközések iránt az intézkedést a rendes törvényes bíróságokra bizza." ${ }^{2}$ Ugyanezt a vonalat követte Győrffy Gyula is felszólalásában, amire már a törvénytervezet hosszúra nyúlt vitájának ${ }^{33}$ a legvégén került sor. Ekkor azt mondta: „Nem szándékozom én, t. ház, a mintául szolgálható államokra hivatkozni, valamint azt hiszem, hogy más részről a t. jobb oldal szónokai sem fognak a franczia államtanácsra, ${ }^{34}$ mint e tekintetben mintára, hivatkozni; de szabad legyen arra figyelmeztetnem a t. házat, hogy a szomszéd örökös tartományoknak 1867. deczember 21-én kelt államtörvényében is az illetőségi kérdések eldöntése egy bíróságra, a Reichsgerichtre van ruházva." 35 A törvényjavaslat förendiházi vitája során ugyanez vetődött fel. Miske Imre báró a következőket mondta: „[M]agam részéről mint ideiglenest elfogadom. De miután más országokban, valamennyi parlamenttel biró országban oly illetékességi esetekre nézve, hol az illetékességre nézve kérdés támad, külön független testület van meghatározva törvény által, igy pl. Francziaországban az államtanács határoz, igy a lajtántúli országokra nézve a törvények külön független testületet állapítottak meg; jegyzőkönyvileg azon óhajt kívánom kifejeztetni, hogy a ministerium részéről e tekintetben egy törvényjavaslat terjesztessék még a törvényhozás elé." ${ }^{36} \mathrm{Ez}$ a javaslat Horváth Döme bizottsági előadó fentebb ismertetett javaslatára rímel, aki szintén kérte rögzíteni országgyülési határozatban azt, hogy a kormány mielőbb egy kiegészítő törvényjavaslatot terjesszen az országgyűlés elé. Ahogyan Horváth Döme javaslatával, úgy Miske Imréével sem történt semmi a későbbiekben. A feladat nehézségét az mutatja, hogy a helyzet ideiglenességét majd csak az 1907. évi LXI. törvénycikk ${ }^{37}$ oldja meg, amely felállítja a Hatásköri Bíróságot.

Horváth Boldizsár a vita zárásakor maga is elismerte, hogy nem a legszerencsésebb és nem is az ideális megoldást választották. „Kényszerüségből vette tehát ezt át a minisztérium egyelőre ideiglenesen, méltóztassanak ebben megnyugodni, s ne mindjárt administrativ absolutismus és szabadság kérdést csinálni belőle. Sőt kijelentem, hogy üdvözölni fogjuk azon pillanatot, mely bennünket e tehertől meg fog menteni." ${ }^{38}$ Nos, erre a pillanatra, amit Horváth Boldizsár annyira várt volna, közel 40 évet kellett még várni.

A hatásköri bíróságokról szóló törvénycikk indokolása visszautalt erre az időszakra, amikor azt mondta ki, hogy „már 1869-ben is érett volt az a gondolat, hogy ez csak ideiglenes rendezés. Jelentékeny államférfiak már akkor is pártatlan bírói fórumot követeltek. Az ily legfelsőbb bíróság szervezetének nehézségei, a felállitandó államtanács eszméje, de főkép az indokolta az ideiglenes rendezést, mert az akkor vezető politikai párt minden

\footnotetext{
31 Ez a rendelet II. Sándor cár igazságügyi reformját jelenti.

32 Képviselőházi napló 1869, II. kötet, 242.

331869 júniusában és júliusában.

34 Conseil d’État. Mezey Barna - Szente Zoltán: Európai alkotmány- és parlamentarizmustörténet. Budapest, Osiris, 2003. 248. és 606.

35 Képviselőházi napló 1869, II. kötet, 493.

36 Főrendiházi napló 1869, I. kötet, 68-69.

37 1907. évi LXI. törvénycikk a hatásköri bíróságokról.

38 Képviselőházi napló 1869, II. kötet, 495.
} 
törekvése az volt, hogy a föreformot: a bírói hatalom elválasztását a közigazgatástól vigye sikerre. A törvényhozásnak az idézett törvénycikkben kilátásba helyezett intézkedése akkor elmaradt, sőt az ideiglenes hatáskör állandósult." ${ }^{39}$ A törvényjavaslat e részével kapcsolatban az a helyzet állt elő, miszerint a kormánypárt és az ellenzék, a centralisták és a municipalisták is egyetértettek abban, hogy a szabályozás így nem megfelelö. Nem helyes a kormányra bízni a közigazgatási hatóságok és bíróságok között felmerült hatásköri összeütközések rendezését, sőt, még abban is egyetértés látszott kibontakozni, hogy vagy a részleteiben ki nem bontott legfelső állambíróság feladat volna ez, vagy pedig valamilyen más bírói szervé.

Ahogyan egyre hosszabbra nyúlt az ideiglenes szabály hatályban léte, a későbbi vélemények sem bántak kesztyüs kézzel a törvény megoldásával. Wlassics Gyula egy röpiratát ${ }^{40}$ idézi a Pesti Hírlap 1880-ban: „[S]zakítnunk kell, mert lehetetlen türni oly állapotot, hogy a kormány, mely a hatásköri összeütközést rendszerint maga provokálja, maga legyen bíró s maga határozza el, hogy valamely ügy a törvény rendes útjára vagy a kormány hatásköréhez tartozik-e." ${ }^{\prime 11}$ A cikkben idézett röpiratban Wlassics és a cikkben a szerző is arra hívja fel a figyelmet, hogy nem egyszerűen arra ad lehetőséget ez a szabályozás, hogy a kormány úgy döntsön el hatásköri összeütközéseket, hogy ahhoz sem a szükséges szakértelemmel nem rendelkezik, sem a szükséges felelősséggel. Egyenesen arra utalnak, hogy ez az ideiglenes szabályozás a hatáskörelvonás eszköze lehet. Csak a kormány önmérsékletén múlik, hogy egy felsőbb utasításra megalkotott hatásköri összeütközésen keresztül nem dönt úgy, hogy a bíróságokra tartozó ügyeket elvon onnan. Wlassics szerint így fennáll az lehetőség, hogy a kormány az államkincstárt terhelő pereket elvonhatja a rendes bíróságok elől. A cikkíró egyébként figyelmezteti a kormányt „a törvényhozás az 1869. IV. t. c. 25. \$-ának e felhozott nagy hiányára”, ${ }^{2}$ Wlassics Gyuláról pedig mint „a fiatal szerzőről” elismerőleg szól, hogy ezt a fontos kérdést napirendre hozta.

Wlassics Gyula máshol arról a hitéről szólt, „hogy [...] a ministertanács jövőben csak elvétve fog azon helyzetbe jönni, hogy az 1869:IV. tcz. 25. \$-a értelmében, bagatell büntető ügyek halmaza fölött legyen kénytelen tanácskozni és határozni”. ${ }^{43}$ Ahogyan az 1869-es törvényhozás munkája során még nem látszott, egy évtizeddel később világossá vált: a hatásköri összeütközések, amelyeket a kormánynak el kell döntenie föleg olyan ügyekben fordulnak elő, amelyek csekély jelentőségűek. Különösen így van ez a kihágások esetében, amelyek eleve a „bagatell büntetőjog” részei, főleg kis súlyuk miatt nem tartoznak a vétségek vagy föleg a büntettek közé. Az eredeti javaslat kritikái között felmerült az, hogy a kormánynak nincsenek meg a szükséges kompetenciái ilyen hatásköri összeütközések eldöntésére. Ez kétségtelenül igaz, ráadásul sokkal kellemetlenebb is, ha ilyen egyszerű megítélésü ügyekről van szó.

1907. évi LXI. törvénycikk indokolása, 2. bek.

Wlassics Gyula: A hatásköri összeütközés ügye. Nagykanizsa, 1880.

A 25-ik §. Pesti Hírlap, 2. (1880), 281. 4.

Uo.

Wlassics Gyula: Hatásköri összeütközések bünügyekben. Büntető Jog Tára, 1. (1881), 21. 321-324. 324. 
Az előbbiekre tekintettel érdemes egy pillantást vetni arra, hogy melyek voltak a főbb témák, amelyekben kormány által eldöntendő hatásköri összeütközés merült fel. Ehhez a Magyar Közigazgatás szerkesztősége által készített, a Közigazgatási határozatok egyetemes gyüjteménye címü (egyébként összesen hatkötetes) kiadványt használtam fel. A kormány által eldöntött hatásköri összeütközések az 1880-as évek és 1908 között a következő témákba voltak csoportosíthatók: közigazgatási és magánjogi ügyek, kihágási ügyek, közegészségügyi kérdések, cselédügyek, mezőrendőrségi ügyek, erdészeti és vadászati ügyek, vízjogi ügyek és közúti ügyek. ${ }^{44} \mathrm{Az}$ első két csoportba tartozott az ügyek többsége, így látható, hogy a kihágásokkal kapcsolatos hatásköri összeütközések jelentős részét adták a kormány ilyen munkájának. A minisztertanácsi jegyzőkönyvek vizsgálatával látható, hogy a kormány által elintézett hatásköri összeütközések száma az 1880-as és az 1890-es években körülbelül 50 évente, majd a századfordulót követően évi 100 körüli ügyet kell eldönteni. A számokból látszik, hogy nem teljesíthetetlen, de számottevő az ügyteher.

\section{EGY TÁL MOSLÉK - A MINISZTERTANÁCS ELŐTTT ${ }^{45}$}

Egy témáját véve valóban bagatell esetet ismertet egy nem ismert árvaszéki ülnök a Pécsi Figyelő hasábjain. ${ }^{46} \mathrm{Az}$ ügy népszerüségére utal, hogy a Pesti Hírlap is ismerteti, ${ }^{47}$ valamint megjelent a Büntetőjog Tárában is. ${ }^{48}$ A történeti tényállás szerint Kapácsi Lídia panaszt emelt a veszprémi kir. járásbíróságnál, hogy Sziládi Benőné szóváltás közben egy tál moslékot öntött fejére. Az ügy kimenetele nem is annyira, sokkal inkább az ügy által megjárt szervek sora az érdekes. A veszprémi kir. járásbíróság végzésével a panaszjegyzőkönyvet áttette a veszprémi szolgabírósághoz, mert álláspontja szerint az eset a Kbtk. 75 . \$-a szerinti közrend elleni kihágásnak minősül, és így az 1880. évi XXXVII. tc. 41. \$1. pontja értelmében az eljárásra a veszprémi szolgabírói hivatal illetékes. A veszprémi szolgabíróság a panaszoltat és két tanút kihallgatott, és arról győződött meg, hogy az eset a Btk. 261. \$-a szerint minősül, és ezért az 1880. évi XXXVII. tc. 40. \$2. pontja értelmében, annak elbírálása, mint járásbírósági hatáskör a járásbíróságra tartozik. Erre tekintettel a szolgabírói hivatal az iratokat Veszprém megye alispáni hivatala útján fölterjesztette a kormányhoz a hatásköri kérdés eldöntése érdekében. A minisztertanács ebben az esetben kimondta, hogy az ügy bírói útra tartozik, mert a történeti tényállás a Btk. 261. \$-a szerint minősülő becsületsértés vétségének ismérveit foglalja magában, és az 1880. évi XXXVI. tc. 40 . $\$$ 2. pontja értelmében a Btk. 261. \$-a szerint büntetendő vétségek a kir. bíróságok hatásköréhez tartoznak.

\footnotetext{
Közigazgatási elvi határozatok egyetemes gyüjteménye. Új folyam. Harmadik kötet. Budapest, Pallas, 1910. Napi hírek. Pesti Hírlap, 3. (1881), 48. 5. és Illetőségi kérdések. Pécsi Figyelö, 9. (1881), 10. 2.

Illetőségi kérdések. Pécsi Figyelö, 9. (1881b), 10. 2.

Napi hírek. Pesti Hírlap, 3. (1881), 48. 5.

Büntetö Jog Tára. 1. (1881), 21. 324.
} 
Látható, hogy az ügyet határozottan és egyértelmüen eldöntötte a minisztertanács. Ennek értékelése előtt vesztegessünk néhány szót arra, hogy a kormány hogyan dönti el a közigazgatási hatóságok és bírói szervek közötti hatásköri összeütközéseket. A legfontosabb talán az - és ez nem merült még fel az 1869-es viták során sem -, hogy a kormány ezt a döntést mindenféle eljárási szabályozás, mindenféle garancia nélkül hozza meg. Erre Wlassics Gyula is felhívja a figyelmet egy írásában. ${ }^{49}$ Nincs jogszabály, amely a kormány e speciális eljárásával kapcsolatban bármilyen részletszabályt tartalmazna. Egyetlen garancia van mindössze, az 1848. évi III. törvénycikk szerinti miniszteri felelősség. A kialakult gyakorlat szerint a hatásköri összeütközés kérdésében a minisztertanács az igazságügy-miniszter elöterjesztése alapján dönt, aki az előterjesztés megtétele elött egyeztet az illetékes miniszterrel..$^{50}$

Bár az ideiglenes szabály hatályban létének közel 40 éve alatt nem merült fel jelentősebb aggály a minisztertanács döntésével kapcsolatban, ha merült is volna, nem lett volna fórum, ahová azzal fordulni lehetett volna. Egy kritikával gyakran illették a kormányt a hatásköri összeütközésekben hozott döntéseivel kapcsolatban: túlságosan lojális volt a bíróságok felé, gyakran a közigazgatás rovására terjesztették ki a bíróságok hatáskörét. ${ }^{51}$

Lássuk, hogy a fentebb írt becsületsértéssel kapcsolatos ügyben, amikor a kormány eldöntötte a hatásköri összeütközést, mit is mondott ki valójában. A minisztertanács döntésének lényegét összefoglaló mondat így hangzik: „A ministertanács ez esetben kimondta, hogy az ügy bírói útra tartozik, mert az elkövetett tény a Btk. 261. §-ában meghatározott becsületsértés vétségének ismérveit foglalja magában, s mert az 1880:XXXVI. tcz. 40. $\$$-a második pontja értelmében a Btk. 261. \$-a szerint büntetendő vétségek a kir. bíróságok hatásköréhez tartoznak.” Ebben az esetben a szóhasználatnak nagy jelentősége van. A minisztertanácsi döntés a tényállás egyes ismérveit azonosítja. Konkrétan azt állítja, hogy a becsületsértés ismérveit látja felismerhetőnek a történeti tényállásban. Kifejezetten nem minősít, nem ítélkezik, de mégis: azt fogalmazza meg, hogy a becsületsértés tényállási elemeit látja felismerhetőnek. Miért kell ilyet tennie? Nagyon egyszerü: azért kell a tényállást azonosítani, mivel ez a hatáskör alapja. Az életbeléptetési törvény (1880. évi XXXVI. törvény) sok esetben a közigazgatási hatóság vagy a bíróság hatáskörét az elkövetetett, elbírálandó büncselekmény alapján állapítja meg.

Mi ennek a döntésnek a következménye? Az 1869. évi IV. törvénycikk 25. \$-a nem határozza meg a minisztertanács döntésének következményeit. Segítségül a hatásköri bíróságokról szóló törvénycikk indokolását lehet felhívni. A törvénycikk 19. \$-ához készült indokolás szerint a „hatásköri bíróság csak a fölött hivatott dönteni, hogy rendes bírói, közigazgatási hatósági vagy közigazgatási bírói útra tartozik-e az eljárás. Arra azonban, hogy a bírói vagy a közigazgatási hatóságok közül melyik bíróságnak vagy melyik közigazgatási

Wlassics Gyula: A „hatásköri összeütközések” bírósága. Jogtudományi Közlöny, 29. (1894), 51. 401-402.

Balogh Jenő - Edvi Illés Károly - Vargha Ferencz: A bünvádi perrendtartás magyarázata: Kiegészítve az esküdtbíróságról s a bünvádi perrendtartás életbelépéséröl szóló törvényekkel 1. Budapest, Grill, 1909. 161.

${ }^{51}$ A hatásköri összeütközések bíróságáról szóló törvényjavaslat. Pesti Napló, 46. (1895), 8. 1. és A hatásköri bíróságról szóló törvényjavaslat. Magyar Közigazgatás, 25. (1907), 46. 1-2. 1. 
hatóságnak kell eljárnia, a hatásköri bíróság nem nyilatkozhatik, mert ez az illetékességi kérdés már bírói vagy közigazgatási útra tartozik. Kimondja továbbá a 19 . $\$$ azt is, hogy a hatásköri bíróságnak határozata mind a bíróságot, mind a közigazgatási hatóságot kötelezi; ezek a hatóságok tehát a hatásköri döntést többé nem tehetik kérdés tárgyává. A hatáskör kijelölésének következménye az is, hogy ha az a hatóság, a mely az ügyre a hatásköri bíróság döntése szerint hatáskörrel nem bírt, érdemben határozott, eljárt vagy intézkedett, ez a határozat, eljárás vagy intézkedés hatályát veszti.” Azaz, a hatásköri összeütközés kérdésében hozott döntés köti a bíróságot, köti a közigazgatási hatóságot, egyiknek kell eljárnia, a másik pedig nem járhat el. Ha a gondolatmeneten továbbmegyünk: a kormány a tényállás valamilyen szintü ismeretében döntést hoz, valaminek minősítenie kell az elkövetett cselekményt annak érdekében, hogy a hatásköri kérdést eldöntse. Azzal, hogy a bírói vagy a közigazgatási út kötött, valamelyest a kormány minősítése is kötötté válik. Így már érthető, hogy a kormány a hatásköri összeütközéseknél miért volt túlzottan óvatos és lojális a bíróságok felé. Ha a megítélésben, minősítésben téved, inkább felfelé tévedjen a bíróságok javára, inkább engedjen teret a szabad ítélkezésnek.

Más esetekben a minisztertanács hatásköri összeütközésekben hozott döntéseinek a szóhasználata más, további aggályokat vet fel. Egy hatásköri összeütközéses ügyben a minisztertanácsi döntés így szólt: „[M]ert ezen tényállás szerint a hatósági közeg hivatalos eljárásában tettleg bántalmaztatott, ezen büntetendő cselekmény pedig bebizonyítás esetén az 1878:V. tcz. 165. \$-a szerint lévén büntetendő, közigazgatási hatóság abban el nem járhat, és mert az 1879:XL. tcz. 46. \$-a melyre a nevezett kir. járásbíróság hivatkozott, csak oly esetekre vonatkozik, a melyekben a hatósági hivatalnok vagy közeg sértő kifejezésekkel illettetik, nem pedig oly esetekre, midőn a hatósági közeg tettleges bántalmazást szenved."52 Ebben az esetben a kormány megállapította a tényállást. Azt mondta kifejezetten, hogy a tényállás szerint bántalmazás történt, a hatósági közeget tettleg bántalmazták. Itt nem minősít, megállapítja a tényállást, és rögzíti, hogy amennyiben ez bizonyítást nyer, akkor a Btk. szerint büntetendő. Egy másik esetben másként, sokkal óvatosabban, finomabban fogalmaz a minisztertanács: „A feljelentett tényállás szerint Sz. Jánosné szül. B. Verona nyílt helyről 2 db. 1 frt értékü kacsát lopott. Ezen cselekmény, tekintettel arra, hogy a kir. Curiának 10. sz. döntvénye szerint az élö kacsa is az élelmi czikk fogalma alá esik, hogy annak összértéke a 2 frtot felül nem haladja s hogy ama körülmények egyike sem panaszoltatik, melyek a lopást bűntetté minősitik: a Kbtk. 126. §-ába ütköző kihágás tényelemeit látszik magában foglalni s minthogy ezen kihágás az 1880:XXXVII. tczikk 41. \$-a értelmében a közigazgatási hatóságok hatáskörébe utalt kihágások között nem foglaltatik, ennek elbírálása ugyanazon tcz. 40. $\$$-a 5 . pontja értelmében a kir. bíróságok hatáskörébe tartozik.” ${ }^{33}$ Itt azt a kifejezést használja, hogy a „kihágás tényelemeit látszik magában foglalni”. Előtte viszont értékeli a tényállás elemeit, és megállapítja, hogy nincs olyan eleme a tényállásnak, amely ezt a cselekmény bűntetté és ne kihágássá minősítené.

52 Büntetö Jog Tára, 1. (1881), 26. 401.

53 Igazságügyi Közlöny, 2. (1893), 10. (1893. október 19.) 265. és Jogtudományi Közlöny, 28. (1893), 43. (1893. október 27.) 344. 
A minisztertanács ebben az ügyben valóságosan bírósági szerepben érzi magát, hivatkozza a Curia döntvényét, annak megfelelően minősít.

\section{6. ÖSSZEFOGLALÁS}

Annak érdekében, hogy a bírósági reform 1869-ben elkezdődhessen, sok kompromiszszumra volt szükség. Ilyen kompromisszum eredménye lett az 1869. évi IV. törvénycikk 25. $§$-a, amely a közigazgatási hatóságok és a bíróságok közötti hatásköri összeütközések rendezésének kérdését szabályozta. A szabályozás bár megszületett, a tartalma nem a legszerencsésebb volt, és eleve ideiglenesnek tervezték. Szerencsétlen volt a szabályozás, mivel a kormánynak olyan kérdésekkel kellett foglalkoznia, amelyekhez sem a szükséges tudása, sem a szükséges kompetenciái, sem pedig a szükséges mennyiségü ideje nem állt rendelkezésre. Ráadásul - különösen a kihágások esetén - olyan ügyeket kellett a kormány elé vinni, amelyek jelentősége nagyon csekély volt. Olyan ügyek voltak ezek föleg, amelyekben a döntést a közigazgatás végein, a legalsó szinteken kellett volna eldönteni. „A fent lett a lent”, azaz tulajdonképpen méltatlan ügyekben kellett a kormánynak döntenie, ahogyan az a fentebb ismertetett moslékos esetben is látszott. A kortársak szerint is a kormány megfelelő önmérséklettel és óvatossággal járt el a hatásköri összeütközések feloldásánál. Azonban erre az önmérsékletre semmilyen jogszabály nem kényszerítette, semmilyen jogi jellegü garanciális elem sem volt a kormány eljárásában. A helyzet valódi megoldását a hatásköri bíróságokról szóló törvény hozta el 1907-ben. 


\section{FELHASZNÁLT IRODALOM}

1. Balogh Jenő - Edvi Illés Károly - Vargha Ferencz: A bünvádi perrendtartás magyarázata: Kiegészítve az esküdtbiróságról s a bünvádi perrendtartás életbelépéséröl szóló törvényekkel 1. Budapest, Grill, 1909.

2. Büntetö Jog Tára, 1. (1881), 21.

3. Büntetö Jog Tára, 1. (1881), 26.

4. Förendiházi napló 1869, I. kötet

5. Igazságügyi Közlöny, 2. (1893), 10. (1893. október 19.)

6. Jogtudományi Közlöny, 28. (1893), 43. (1893. október 27.)

7. Képviselöházi Irományok, 1. (1869), 1-104.

8. Képviselőházi napló 1869, II. kötet.

9. Kilián Zoltán: Erdei kihágás. Napkelet, 4. (1926), 9. 846-853.

10. Közigazgatási elvi határozatok egyetemes gyüjteménye. Új folyam. Harmadik kötet. Budapest, Pallas, 1910.

11. Mezey Barna - Szente Zoltán: Európai alkotmány- és parlamentarizmustörténet. Budapest, Osiris, 2003.

12. Nagy Miklós: Ghyczy Kálmán, mint nádori ítélőmester. Budapesti Szemle, 219. (1930), 635. 1-28.

13. A 25-ik $\S$. Pesti Hírlap, 2. (1880), 281. 4.

14. A hatásköri bíróságról szóló törvényjavaslat. Magyar Közigazgatás, 25. (1907), 46. 1-2.

15. A hatásköri összeütközések bíróságáról szóló törvényjavaslat. Pesti Napló, 46. (1895), 8.

16. Illetőségi kérdések. Pécsi Figyelö, 9. (1881), 10. 2.

17. Napi hírek. Pesti Hírlap, 3. (1881), 48. 5.

18. Wlassics Gyula: A hatásköri összeütközés ügye. Nagykanizsa, 1880.

19. Wlassics Gyula: A „hatásköri összeütközések” bírósága. Jogtudományi Közlöny, 29. (1894), 51. 401-402.

20. Wlassics Gyula: Hatásköri összeütközések bűnügyekben. Büntető Jog Tára, 1. (1881), 21. 321-324. 
Jogi források

1. 1848. évi III. törvénycikk független magyar felelős ministerium alakításáról

2. 1868. évi L. törvénycikk az 1869-ik évi államköltségvetésről

3. 1869. évi IV. törvénycikk a birói hatalom gyakorlásáról

4. 1869. évi XXVI. törvénycikk az olasz királysággal 1869. évi február hó 27-én a közbüntettesek kölcsönös kiadása tárgyában kötött államszerződésről

5. 1870. évi IV. törvénycikk az 1869. évi XXVI. törvénycikk hatályának kiterjesztéséről

6. 1870. évi XLIV. törvénycikk a honvédelmi ministernek 1870. évre megszavazandó öt millió forintnyi póthitelről

7. 1870. évi XLV. törvénycikk a közbiztonság helyreállitása végett tett rendkivüli intézkedések befejezéséhez megkivántató póthitelről

8. 1870. évi XLVIII. törvénycikk az 1871. évi január 1-től ugyanazon évi február végeig viselendő közterhekről és fedezendő kiadásokról

9. 1871. évi II. törvénycikk az 1871. évi márczius hóban viselendő közterhekről és fedezendő kiadásokról

10. 1871. évi X. törvénycikk az 1871. évi államköltségvetésről

11. 1878. évi V. törvénycikk a magyar büntetőtörvénykönyv a büntettekről és vétségekről

12. 1879. évi XL. törvénycikk a magyar büntető törvénykönyv a kihágásokról

13. 1879. évi XXXI. törvénycikk Erdőtörvény

14. 1880. évi XXXVII. törvénycikk a magyar büntető-törvénykönyvek (1878:V. törvénycikk és 1879:XL. törvénycikk) életbeléptetéséről

15. 1907. évi LXI. törvénycikk a hatásköri biróságokról

16. A földmivelés-, ipar- és kereskedelemügyi m. kir. minister által 24,432. szám alatt kiadott utasitás, az erdei kihágási biróságok által használandó érték- és árszabályzatok kidolgozásánál követendő eljárás tárgyában

17. A földmivelés-, ipar- és kereskedelemügyi m. kir. minister által 24,931. szám alatt kiadott utasitás, az erdei kihágások feljegyzésére szolgáló erdei rovatos naplók készitése és vezetése tárgyában

18. A m. k. igazságügyministernek 1871. decz. 12-én 10.222. sz. a. kelt utasítása a szervezendő kir. bíróságok életbeléptével feloszlatandó elsőfolyamodásu biróságok iratainak, az ezek által kezelt letéteknek, telekkönyveknek átadása, valamint a törvényhatósági börtönök s fogházakban letartóztatott foglyok átszállítása tárgyában

19. A m. kir. belügyministernek 37,635. számú körrendelete, az uj erdőtörvény életbelépte előtt elkövetett erdei kihágások elbirálása tárgyában

20. A m. kir. vallás- és közokt. ministertől 1871. október 10-én 22.392. szám alatt kiadott szolgálati utasítás a közalapítványi kir. erdészek számára

21. A vallás és közoktatási m. k. ministernek 1875. évi 20,377. sz. a. valamennyi megye tanfelügyelöjéhez és az egyházi hatóságokhoz intézett körlevele: a községi faiskolák berendezése tárgyában 
Levéltári források

1. MNL W12 Minisztertanácsi jegyzőkönyvek (K27) 1867-1944. 1870. július 21. (53. ülés)

2. MNL W12 Minisztertanácsi jegyzőkönyvek (K27) 1867-1944. 1878. december 27. (42. ülés)

3. MNL W12 Minisztertanácsi jegyzőkönyvek (K27) 1867-1944. 1884. március 18. (8. ülés)

4. MNL W12 Minisztertanácsi jegyzőkönyvek (K27) 1867-1944. 1885. június 8. (12. ülés)

5. MNL W12 Minisztertanácsi jegyzőkönyvek (K27) 1867-1944. 1897. február 10. (6. ülés) 
Bathó Gábor jogász, közgazdász. Jogászként 2009-ben szerzett oklevelet az Eötvös Loránd Tudományegyetemen, 2012 és 2015 között a Pázmány Péter Katolikus Egyetem Jog- és Államtudományi Doktori Iskolájának doktorandusza volt. 2019-ben tett jogi szakvizsgát. Diplomájának megszerzése óta a felsőoktatási igazgatásban dolgozott, több intézményben (Budapesti Kommunikációs és Üzleti Főiskola, Budapesti Corvinus Egyetem, Wekerle Sándor Üzleti Főiskola), különböző beosztásokban. 2005 óta oktat, először felsőfokú szakképzésben, majd 2012-től a felsőoktatásban elsősorban alkotmány- és jogtörténeti, valamint bevezető jogi és igazgatási jellegü tárgyakat. Jelenleg a Nemzeti Közszolgálati Egyetem Államtudományi és Nemzetközi Tanulmányok Karán működő Állam- és Jogtörténeti Tanszék tanársegédje, illetve az Alkotmánybíróság tanácsadója. Kutatási területei a parlamenti jog, a magyar kormány szervezete és működése és a hatásköri összeütközések. 